\title{
The Centris bees described by Ezra Townsend Cresson (Hymenoptera: Apidae)
}

\author{
Felipe Vivallo (1)
}

\begin{abstract}
Laboratório de Hymenoptera HYMN, Departamento de Entomologia, Museu Nacional/ Universidade Federal do Rio de Janeiro. Horto Botânico, Quinta da Boa Vista - São Cristóvão, 20940-040 Rio de Janeiro, RJ, Brazil.
\end{abstract}

ABSTRACT. In this paper the primary types of bees of the genus Centris Fabricius, 1804 described by the American hymenopterologist Ezra Townsend Cresson were studied. The type specimens of C. aethiops, C. fulviventris, C. lanosa, C. montezuma, C. otomita, and C. totonaca were examined, providing notes on their current status and depository. Photographs of selected types are also provided.

KEYWORDS. Anthophila, Centridini, Neotropical Region, Solitary Bees, Taxonomy.

RESUMO. As abelhas Centris descritas por Ezra Townsend Cresson (Hymenoptera: Apidae). Neste artigo foram estudados os tipos primários das abelhas do gênero Centris Fabricius, 1804 descritas pelo himenopterólogo americano Ezra Townsend Cresson. Os espécimes-tipo de C. aethiops, C. fulviventris, C. lanosa, C. montezuma, C. otomita e C. totonaca foram analisados, fornecendo notas sobre seu status atual e local de depósito. Fotografias de alguns tipos selecionados também são proporcionadas.

PALAVRAS-CHAVE. Anthophila, Centridini, Região Neotropical, Abelhas Solitárias, Taxonomia.

In the middle of the $19^{\text {th }}$ century, France was the center of research in Zoology, including Entomology (CALVERT, 1928). At that time, some remarkable series of taxonomic volumes were published, including those on Orthoptera by Jean GuillaumeAudinet-Serville(1775-1858), Neuroptera by Jules Pierre Rambur (1801-1870) and Hymenoptera by Amédée Louis Michel Lepeletier de Saint Fargeau (17701845) and Gaspard Auguste Brullé (1809-1873) (CALVERT, 1928). In Switzerland, Henri Louis Frédéric de Saussure (1829-1905) was actively in the study of the Hymenoptera, giving special attention to some American representatives of the order (CALVERT, 1928). In England, Frederick Smith (1805-1879) was vigorously working in the British Museum in the study of hymenopteran from several parts of the world (CAlvert, 1928).

On the other side of the Atlantic, in the United States the Smithsonian Institution had been established in Washington D.C. in 1846 and under the direction of its secretary, the American physics Joseph Henry (1797-1878) was beginning it encouragement of the study of Zoology and Entomology of North America (CALVERT, 1928). In 1859, three entomologists, James H. Ridings (1803-1880), George Newman (1801-1876) and Ezra Townsend Cresson (1838-1926) met together with the view of forming a society "whose objectives shall be the advancement of entomological science by ascertaining the name, locality and habits of insects found within the United States" (CALVERT, 1928). For this reason, the Entomological Society of Philadelphia (name changed to The American Entomological Society in 1867) was created (ANONYMOUS, 1926; CALVERT, 1928). Of the three founding partners, Cresson was the youngest, at that time not yet twenty-one years old (CALVERT, 1928). With the passage of time he would become one of the greatest Hymenopterologist of the United States (EssIG, 1931).

In 1861, the Society inaugurated its "Proceedings of the Entomological Society of Philadelphia" (CALVERT, 1928) where Cresson made a very efficient work as editor. He also did this labor in the "Transactions of the Entomological Society of America" for 42 years (CALVERT, 1928) and in the "Entomological News" for 37 years (HoLland, 1927). Cresson also edited "The Practical Entomologist" which was gratuitously distributed among farmers and agriculturists, being the first journal devoted to economic entomology published in the United States (HoLland, 1927).

In the first volume of the "Proceedings" CRESSON (1861) published his first extensive paper "Catalogue of the Cicindelidae of North America". However, he realized that the beetles had received much attention from his predecessors and he focused on other insects group (CALVERT, 1928). Thus, between 1861 and 1882, Cresson produced 66 articles, series of catalogues, synopses and monographs on the Hymenoptera of North America (CALVERT, 1926), an average of more than 
three papers per year (CALVERT, 1928). He also summarized in a comprehensive "Synopsis of the Families and Genera of the Hymenoptera of America north of Mexico", along with a catalogue of the described species and bibliography in 1887 (ANONYMOUS, 1926).

Cresson began to describe North American Hymenoptera in 1861, but his most important work on bees belongs to the year 1878. During his period of activity he proposed 601 names (CALVERT, 1928) in this group, most of which are currently considered valid.

The Cresson's bees of the genus Centris. Cresson described new species in different bee genera, including a few in Centris Fabricius, 1804. His first contribution on the knowledge of the genus was in 1863 when he cited a list and distribution records of some species from North America (Cresson, 1863). Two years later, he described his first three species: Centris aethiops Cresson, 1865, C. cornuta Cresson, 1865, and C. fulviventris Cresson, 1865, all of them from Cuba, Greater Antilles. Some years later, Cresson published an article on Cuban Hymenoptera, describing $C$. armillata Cresson, 1869, based on a single male specimen also collected in that country. In 1872, he published an article on hymenopteran from Texas, southern United States. In that article he described some new species of bees, including $C$. lanosa Cresson, 1872.

Cresson (1879a) published his "Catalogue of North American Apidae", citing almost all species of Centris bees known until that year occurring in that part of the continent, including the Caribbean. In that article he proposed $C$. smithii Cresson, 1879 as new name for $C$. apicalis Smith, 1874 (junior secondary homonym of Anthophora versicolor var. apicalis Guérin-Méneville, $1844=C$. varia (Erichson, 1848)). In the same year, he described C. montezuma Cresson, 1879b, C. totonaca Cresson, $1879 \mathrm{~b}$ and C.otomita Cresson, 1879b from Mexico.

In 1916 "The Cresson types of Hymenoptera" was published, citing all species described by him (CRESSON, 1916). In that paper he mentioned a single specimen as the primary type of the species, designating inadvertently the lectotypes in those taxa described from type series. In the case of Centris bees, there were designated the lectotypes for C. lanosa and C. montezuma.

The purpose of this article is to study taxonomically the species of Centris bees described by E. T. Cresson. For this, their taxonomic status is evaluated, providing information on the condition and depository of the primary types used by him to describe each taxon. Relevant notes on the morphology of the species studied, as well as some photographs, are also provided.

\section{MATERIAL AND METHODS}

The morphological terminology follows MiCHENER (2007). The labels of the specimens studied are yellowish white (due to the effect of time) and rectangular, and the data contained on them is black, handwritten or printed, unless otherwise indicated. The specific features of the labels, like coloration or type of writing are presented in squared brackets ([]). The type specimens here studied are housed at the Academy of Natural Sciences, Philadelphia, United States (ANSP) and Instituto de Ecología y Sistemática (formerly Instituto de Zoología, Academia de Ciencias), La Habana, Cuba (IESH). The copyright of all photographs belongs to the ANSP.

\section{RESULTS}

Recognition of the Cresson's Centris primary types. In 1901, Cresson presented his collection of Hymenoptera to the American Entomological Society, comprising 2,367 types and 3,511 species (CALVERT, 1928). The total number of specimens was estimated at 87,775 (SKINNER, 1901). The type specimens of the species of Centris are currently housed at ANSP and IESH. In general, all primary types are well curated and in good condition. Cresson's descriptions are, considering the time and conditions under which he worked, extremely satisfactory (CALVERT, 1928), turning easy the identification of the species proposed by him.

\section{SYSTEMATICS}

\section{Centris (Hemisiella) Moure, 1945}

\section{Centris (Hemisiella) fulviventris Cresson, 1865}

Centris fulviventris CRESSON, 1865. 4:193, 194.

Type data. Cresson described this species based on a single female collected in Cuba. The holotype is housed at IESH and has the following data label: [light brown label with black rim] Centris fulviventris. [handwritten] 168 [printed]। [squared label with black rim] $\mathrm{Cr}$ [handwritten] (IESH).

Type locality. Greater Antilles: Cuba.

Comments. The type specimen, as well of those of $C$. cornuta and C. armillata belong to the Gundlach collection. Johannes Christoph Gundlach (1810-1896) was a GermanCuban naturalist and taxonomist. In 1839, he left Europe to make collections on the Caribbean island of Cuba, where he lived ever since (VILARó, 1897). In 1875, he changed his name from Johannes Christoph to its Spanish equivalent Juan Cristóbal. He wrote the first major work on the birds (GuNDLACH, 1876), reptiles (GUNDLACH, 1880) and insects of Cuba (GundLach, 1881, 1886, 1891, 1922). The type locality cannot be further narrowed down than to Cuba. This is the only species of $C$. (Hemisiella) recorded in that country.

\section{Centris (Hemisiella) montezuma Cresson, 1879}

$$
\text { (Figs 1-4) }
$$

Centris montezuma CRESSON, 1879b.7:213. Junior synonym of $C$. vittata Lepeletier, 1841 (SNELLING, 1966). 

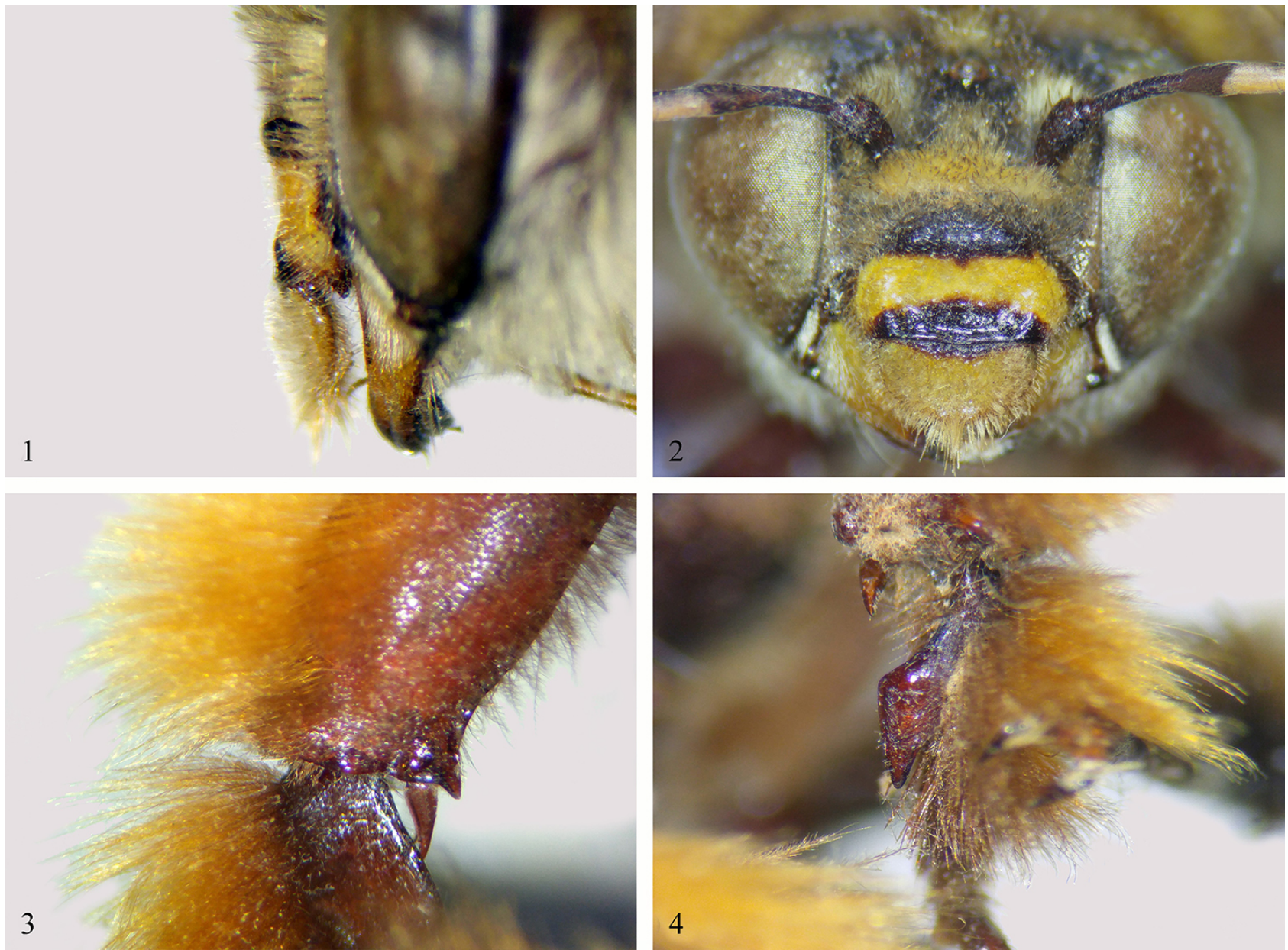

Figs 1-4. Centris montezuma Cresson, 1879, lectotype male: 1, clypeus and labrum, lateral view; 2, head, frontal view; 3, lower margin of hind tibia; 4, spine-like projection on the posterior margin of hind basitarsus.

Type data. This species was described based on two males collected in an undetermined locality in Mexico. Cresson (1916) designated the lectotype which is currently housed at ANSP. The specimen has the following data label: Mex. [printed] [red label] LectoTYPE [printed] 2625 [handwritten] (ANSP).

Type locality. Mexico.

Comments. The lectotype was collected by the Swiss ornithologist Francis Sumichrast (1828-1882), the same collector of the type specimens of $C$. totonaca and $C$. otomita (see below). The specimen designated the lectotype is relatively large and has the spine-like projection on the posterior margin of the hind basitarsus, present in males of the subgenus $C$. (Hemisiella), quite developed (Fig. 4). This makes it seem different from $C$. vittata, since the males of this later species are usually a bit smaller. Both the difference in body size and that of the projection of the hind basitarsus seem to be due only to a matter of scale, since the smaller males have proportionally a reduced projection. This is also found in the spine-like projection of the distal end of the hind tibia (Fig. 3), which is also variable in males of this species.

Both sexes of this species have the pubescence on mesoscutum, mesoscutellum and vertex with black tips and the clypeal disc transversally concave (Figs. 1,2). Photos of both sexes of this species can be found in VIVALlo \& Zanella (2012). The type locality of C. montezuma cannot be further narrowed down than to Mexico. This species occurs from Mexico to Paraguay (Moure et al. 2007).

\section{Centris (Heterocentris) Cockerell, 1899}

\section{Centris (Heterocentris) cornuta Cresson, 1865}

Centris? cornuta CREsson, 1865. 4:194, 195.

Type data. Cresson described this species with doubts about whether it belonged to Centris or not, given its particular morphology. It was described based on a single female specimen collected in an unknown locality in Cuba. The holotype is housed at IESH (Gundlach collection) and unfortunately it was not available during the development of this article.

Type locality. Greater Antilles: Cuba.

Comments. This is one of the morphologically rarest species of the genus, so far only known from female specimens. They have mandibles dark brown, longer than the length of the compound eye (in frontal view) with two 
teeth relatively similar in size on the distal half; disc of the mesoscutum and dorsal surface of hind tibia with brown pubescence and metasoma dark brown. Unfortunately it is not easy to find in collections and nothing is known about its bionomy. Photographs can be found in VéLEZ \& VIVALlo (2012). The type locality cannot be further narrowed down than to Cuba. According to Moure et al. (2007), this species has been also recorded in Haiti.

\section{Centris (Heterocentris) otomita Cresson, 1879}

(Figs 5, 6)

Centris otomita Cresson, 1879b. 7:214. Junior synonym of $C$. analis (Fabricius, 1804) (Moure, 1960).

Type data. This species was described based on a single male specimen collected in an undetermined locality in Mexico. The holotype is housed at ANSP and it has the following data label: Mex. [printed] \[red label] HoloTYPE [printed] 2627 [handwritten] (ANSP).
Type locality. Mexico.

Comments. The holotype was collected by Sumichrast, the same collector of the type specimens of C. montezuma and C. totonaca. Michener (1954) proposed C. otomita as a junior synonym of $C$. totonaca, and subsequently MourE (1960) synonymized this latter species with $C$. analis. Males of this species can be identified by the tridentate mandibles with the innermost teeth reduced and close to each other, the yellow spot on the anterior surface of the scape (Fig. 5) and by the mostly blackish pubescence on T2-T4 (Fig. 6). This is the most common and widely distributed species of C. (Heterocentris). It has been recorded from Mexico to southeastern Brazil (Moure et al., 2007). The type locality of C. otomita cannot be further narrowed down than to Mexico.

\section{Centris (Heterocentris) totonaca Cresson, 1879} (Figs 7, 8)

Centris totonaca CRESSON,1879b. 7:213, 214. Junior synonym of C. analis (MOURe, 1960).
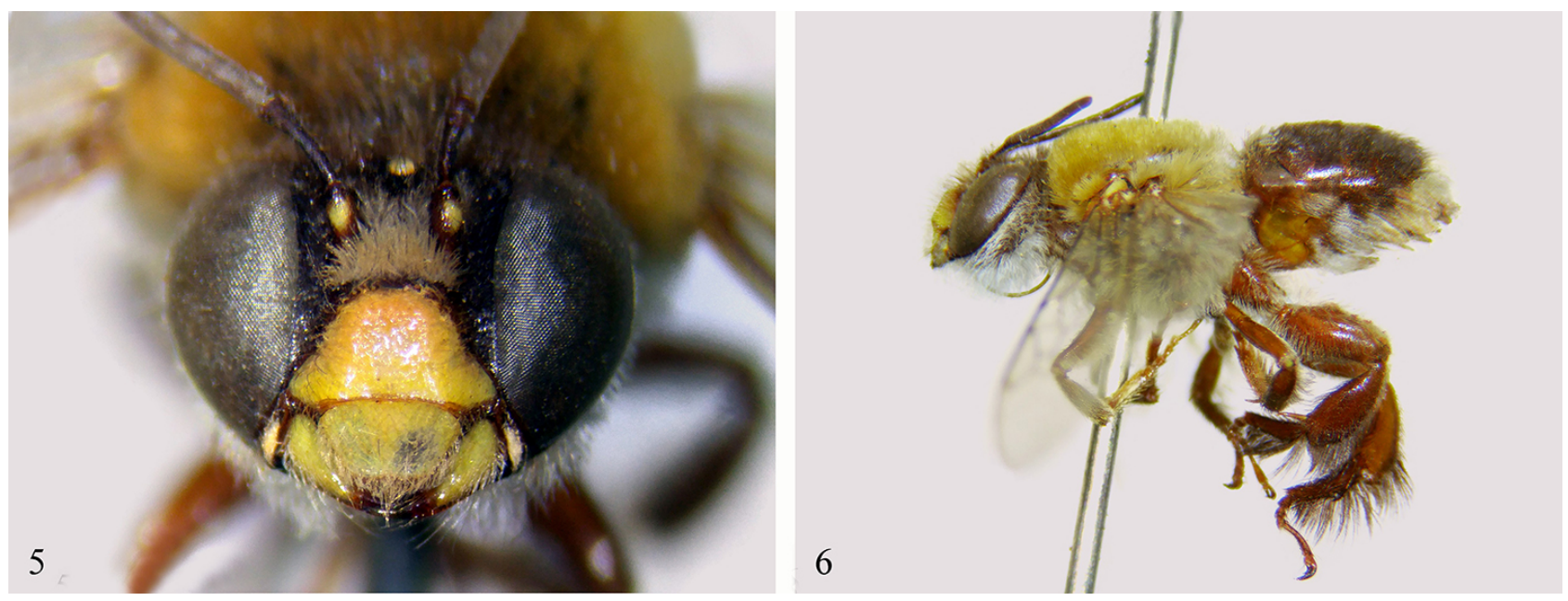

Figs 5, 6. Centris otomita Cresson, 1879, holotype male: 5, head, frontal view; 6, habitus, lateral view.
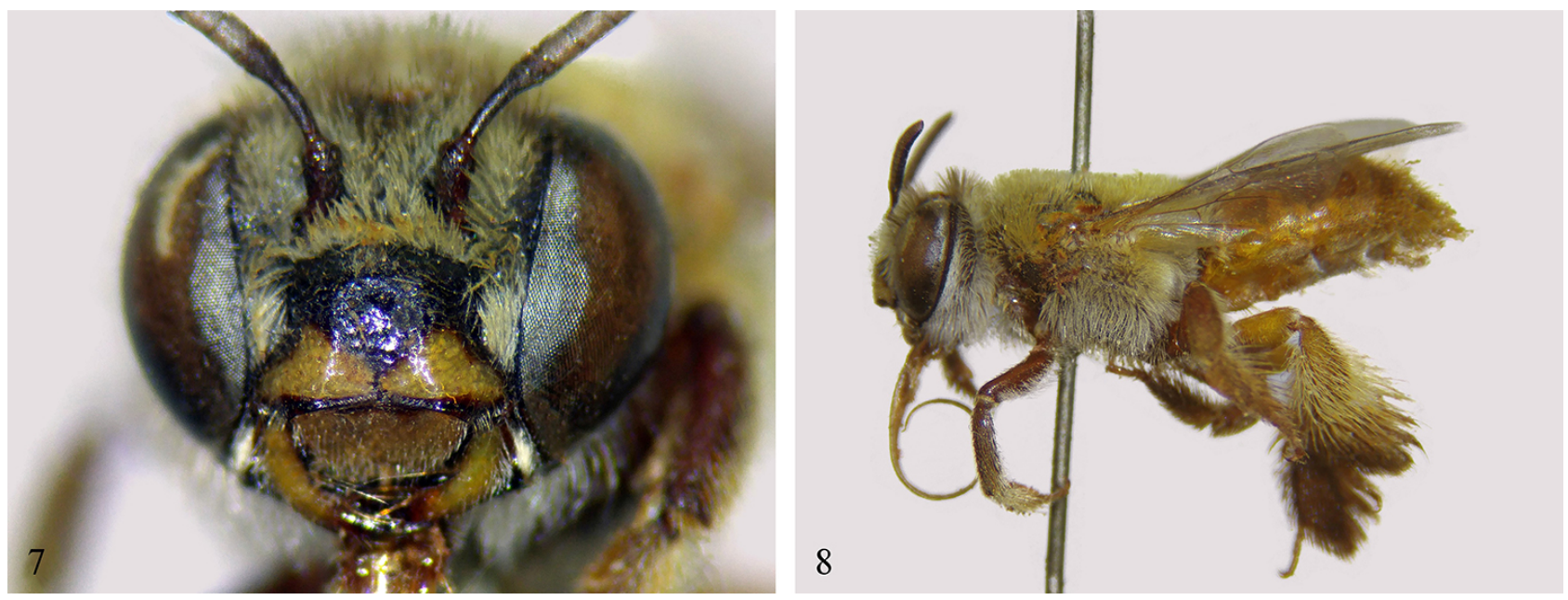

Figs 7, 8. Centris totonaca Cresson, 1879, holotype female: 7, head, frontal view; 8, habitus, lateral view. 
Type data. This species was proposed based on a single female collected in Mexico. The holotype is housed at ANSP and has the following data label: Mex. [printed] $\backslash$ [red label] HoloTYPE [printed] 2626 [handwritten] (ANSP).

Type locality. Mexico.

Comments. The specimen was collected by Francis Sumichrast, the same collector of the type specimens of C. montezuma and C. otomita. Females of this species can be identified by the two yellow triangles on clypeus and the smooth and shiny integument between the punctures of the clypeal disc (Fig. 7), the orange brown metasoma, the scopa whitish on tibia and brownish on basitarsus (Fig. 8) and by the orange lanceolate hairs on the lower corner of the pronotum. Photos of both sexes of this species can be found in Vivallo \& Zanella (2012). The type locality cannot be further narrowed down than to Mexico.

\section{Centris (Paracentris) Cameron, 1903}

\section{Centris (Paracentris) lanosa Cresson, 1872} (Figs. 9, 10)

Centris lanosa CRESSON, 1872. 4:284.

Type data. Cresson (1872) described this species based on three males collected in Texas, southern United States. In 1916, he designated the lectotype which is currently housed at ANSP. The specimen has the following data label: Tex. [printed] $] \widehat{\partial}$ [printed] $\backslash[$ red label] LectoTYPE [printed] 2624 [handwritten] (ANSP).

Type locality. United States: Arizona state: Texas.

Comments. The type series were collected by the Swedish collector Gustaf Wilhelm Belfrage (1834-1882). He was a prodigious collector and one of the best of his time. According to GEISER (1933) the number of new and interesting species discovered by Belfrage was astonishing, considering that they were collected in a very limited area of Arizona State. During 1866, Belfrage entered into correspondence with several entomologists, including Cresson. They encouraged him to make a trip to Texas to collect insects (GEISER, 1933) during which the type specimens of $C$. lanos $a$ were collected. The females have the first flagellomere slightly shorter than the following three segments combined and the metasoma with bluish metallic reflections. Males can be identified by the yellowish hairs on head and mesosoma (Fig. 10), by the paraocular area, the base of the mandible and the anterior surface of the scape yellow (Fig. 9); and by the clypeus with relatively dense punctation, except for a longitudinal unpunctate median line on disc. Centris lanosa has been recorded in the American states of Oklahoma, Kansas, Texas and Florida (Moure et al., 2007).

\section{Centris (Xanthemisia) Moure, 1945}

\section{Centris (Xanthemisia) aethiops Cresson, 1865}

(Figs. 11, 12)

Centris aethiops CRESSON, 1865.4:193.

Type data. This species was described based on a single female specimen collected in an unknown locality in Cuba. The holotype is housed at ANSP and has the following data label: 109 ㅇ [handwritten] $\backslash$ Cuba. [printed] $\backslash$ [red label] HoloTYPE [printed] 2623 [handwritten] (ANSP).

Type locality. Greater Antilles: Cuba.

Comments. Centris caymanensis Vivallo, 2014; C. domingensis Dalla Torre, 1896 and C. aethiops are the only species of $C$. (Xanthemisia) present in the Caribbean, being the latter species the only that has been recorded in Cuba. The female has the body completely covered by dark brown pilosity (Figs. 11, 12), except for the light brown or yellowish pilosity near the pronotal lobe, and the clypeus and terga with relatively uniform punctation. Photos of both sexes can be found in Vivallo (2014). This species has been recorded in Bahamas, Cuba and Jamaica (VIvallo, 2014). The type locality cannot be further narrowed down than to Cuba.
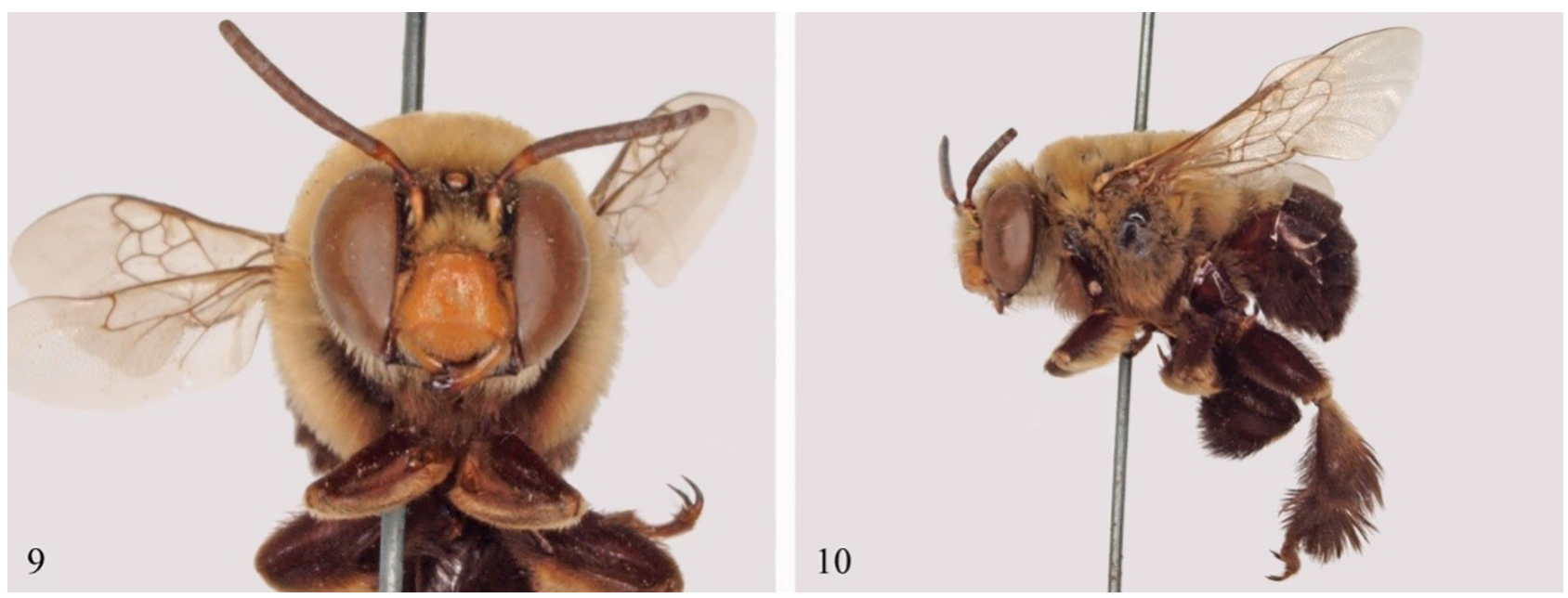

Figs 9, 10. Centris lanosa Cresson, 1872, lectotype male: 9, head, frontal view; 10, habitus, lateral view. 

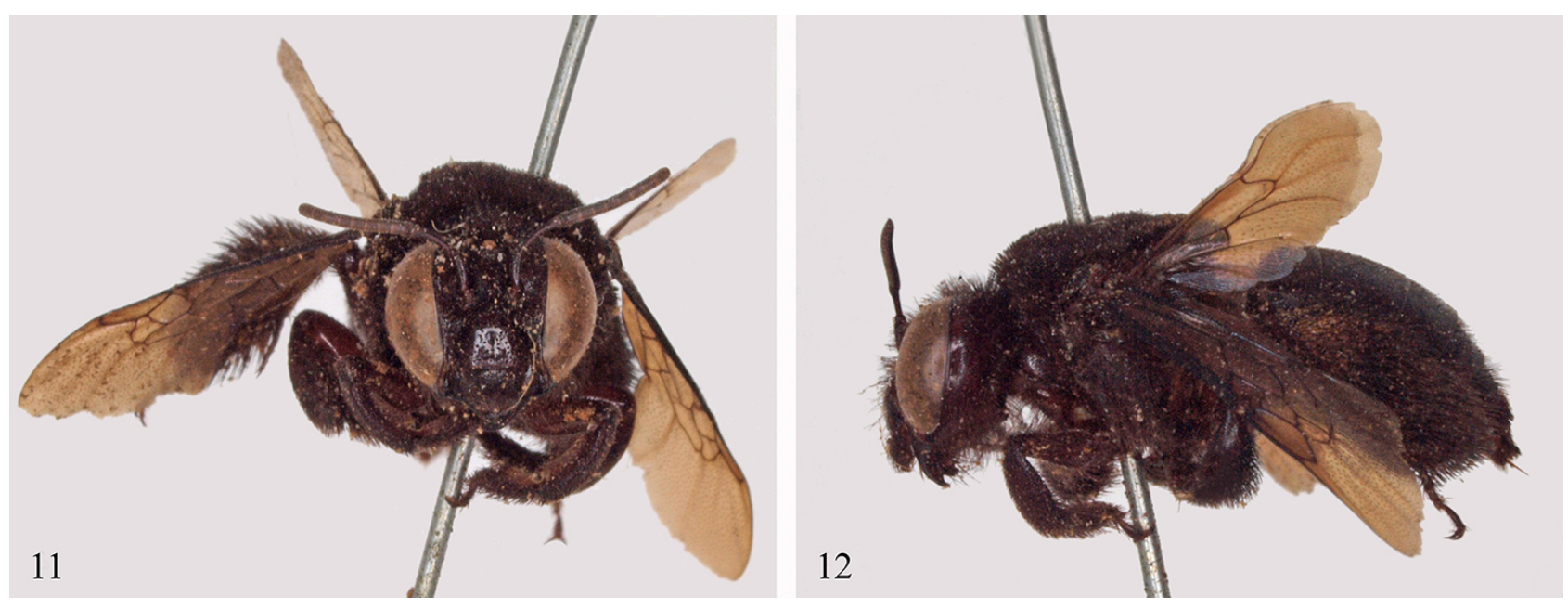

Figs 11, 12. Centris aethiops Cresson, 1865, holotype female: 11, habitus, frontal view; 12, habitus, lateral view.

\section{Centris (Xanthemisia) armillata Cresson, 1869}

Centris armillatus CREsson, 1869. 2:298. Junior synonym of C. aethiops (SNELLING, 1966).

Type data. Cresson proposed this new species based on a single male specimen collected in an unknown locality in Cuba. The holotype is housed at IESH (Gundlach collection) and unfortunately it was not available during the development of this article.

Type locality. Greater Antilles: Cuba.

Comment. The male of this species has the mesoscutum with a band of pale yellow pilosity on the anterior margin, contrasted with the blackish pubescence of the rest of the body; and the punctation of the clypeus is uniformly distributed. The type locality cannot be further narrowed down than to Cuba.

\section{DISCUSSION}

Ezra Cresson is one of the greatest hymenopterologists of all time. During his long and active life he published many articles, which became classic in the literature of Hymenoptera (Holland, 1927). As a writer upon that order, he held the same rank that was held by his contemporaries and fellow-workers, John Lawrence LeConte (1825-1883) and George Henry Horn (1840-1897), who wrote on Coleoptera (Holland, 1927). He was also a dedicated and very systematic researcher, which is reflected in his catalogues and synopsis. Although he did not describe an expressive number of new species in the genus Centris, he did it in a very detailed way. This contrasts with other melittologists of his time, such as Theodore Dru Alison Cockerell (1866-1948) and Heinrich Friese (1860-1948), who used to describe their species in just a couple of lines, making it difficult until today to recognize their species without studying the type material (VIVALLO, 2020).

Unfortunately, the primary types of C. cornuta and C. armillata were not available during the realization of this article. However, thanks to the original descriptions, the identity of both species is clear, which facilitates their identification and avoids future taxonomic problems in this interesting and complex genus of New World bees.

Acknowledgments. I thank Jason Weintraub (ANSP) for allowing me to visit his institution to study the specimens under his care. I also thank Julio Genaro (Caribbean Natural History Group) and the anonymous reviewers for their help. Financial support was provided by Conselho Nacional de Desenvolvimento Científico e Tecnológico (CNPq, grant 444320/2014-8), Brazil. This paper is part of the SIGMA project No21565 MN/UFRJ and contribution number 43 from the HYMN.

\section{REFERENCES}

Anonymous. 1926. Ezra Townsend Cresson. Entomological News 37(6):161-165.

Calvert, P. P. 1926. Ezra Townsend Cresson. Science 64:8-9. https://doi. org/10.1126/science.64.1644.8

Calvert, P. P. 1928. Ezra Townsend Cresson: a contribution to history of entomology in North America. Transactions of the American Entomological Society 53(4):i-lxiv.

Cresson, E. T. 1861. Catalogue of the Cicindelidae of North America. Proceedings of the Entomological Society of Philadelphia 1:7-20.

Cresson, E. T. 1863. Catalogue of the described species of North American Hymenoptera. Proceedings of the Entomological Society of Philadelphia 1(10):316-344.

Cresson, E. T. 1865. On the Hymenoptera of Cuba. Proceedings of the Entomological Society of Philadelphia 4:1-200.

Cresson, E. T. 1869. Notes on Cuban Hymenoptera, with descriptions of new species. Transactions of the American Entomological Society 2:293-298. https://doi.org/10.2307/25076211

Cresson, E. T. 1872. Hymenoptera Texana. Transactions of the American Entomological Society 4:153-292. https://doi.org/10.2307/25076272

Cresson, E. T. 1879a. Catalogue of North American Apidae. Transactions of the American Entomological Society 7:215-232. https://doi. org $/ 10.2307 / 25076374$

Cresson, E. T. 1879b. Descriptions of new North American Hymenoptera in the collection of the American Entomological Society (Family Apidae). Transactions of the American Entomological Society 7:201-232.

Cresson, E. T. 1916. The Cresson types of Hymenoptera. Memoirs of the American Entomological Society 1:1-141.

Essig, E. O. 1931. A History of Entomology. New York, The Macmillan Company.1029p.

Geiser, S.W. 1933. G. W. Belfrage's Texas localities. Entomological News 44:127-132. 
Gundlach, J. 1876. Contribución á la Ornitologia Cubana. Imprenta La Antillana, de N. Cacho-Negrete. 364p.

Gundlach, J. 1880. Contribución á la Herpetologia Cubana. Habana, Imprenta de G. Montiel. 97p.

Gundlach, J. 1881. Contribución á la Entomologia Cubana. Tomo 1. Habana, Imprenta de G. Montiel. 445p.

Gundlach, J. 1886.Contribución á la Entomologia Cubana. Tomo 2. Imprenta La Antillana, de N. Cacho-Negrete. 396p.

Gundlach, J. 1891. Contribución á la Entomologia Cubana. Tomo 3. Habana, Imprenta de A. Alvarez y Comp. 494p.

GundLACH, J. 1922. Contribución a la Entomologia Cubana. Parte cuarta Ortopteros. New York, Facsimile Edition, p. 325-335.

Holland, W. J. 1927. Obituary Ezra T. Cresson. Annals of the Carnegie Museum 17:195-196.

Michener, C. D. 1954. Bees of Panama. Bulletin of the American Museum of Natural History 104(1):1-175.

Michener, C. D. 2007. The Bees of the World. $2^{\text {ed. }}$ Baltimore, Johns Hopkins University Press. 992p.

Moure, J. S. 1960. Notes on the types of the Neotropical bees described by Fabricius (Hymenoptera: Apoidea). Studia Entomologica 3(1\4):97160.

Moure, J. S., Melo, G. A. R. \& Vivallo, F. 2007. Centridini Cockerell \& Cockerell. in: Moure, J. S., Urban, D. \& Melo, G. A. R. eds. Catalogue of Bees (Hymenoptera: Apoidea) in the Neotropical
Region. Sociedade Brasileira de Entomologia, Curitiba, Brazil, p.83-142.

Skinner, H. 1901. Report of the Entomological section. Proceedings of the Academy of Natural Sciences of Philadelphia 53:771-772.

SNelling, R. R. 1966. The taxonomy and nomenclature of some North American bees of the genus Centris with descriptions of new species (Hymenoptera: Anthophoridae). Contributions in Science Natural History Museum Los Angeles County 112:1-33.

VÉLEZ, D. \& Vivallo, F. 2012. A new South American species of Centris (Heterocentris) Cockerell, 1899 with a key to the species with hornlike projections on the clypeus (Hymenoptera: Apidae: Centridini). Zootaxa 3357:49-55. http://dx.doi.org/10.11646/zootaxa.3357.1.4

VILARó, J. 1897. Sketch of John Gundlach. Appleton's Popular Science Monthly 50:691-697.

VIVALLO, F. 2014. Revision of the species of Centris (Xanthemisia) Moure, 1945 (Hymenoptera: Apidae: Centridini) from the Caribbean Islands. Zootaxa 3821(1):58-70. http://dx.doi.org/10.11646/zootaxa.3821.1.4

Vivallo, F. 2020. The bees of the genus Centris Fabricius, 1804 described by Theodore Dru Alison Cockerell (Hymenoptera: Apidae). European Journal of Taxonomy 618:1-47.

Vivallo, F. \& Zanella, F. C. V. 2012. A new species of Centris (Paracentris) Cameron, 1903 from northeastern Brazil, with a key for the Centris species of the Caatinga region (Hymenoptera: Apidae). Zootaxa 3298:116. http://dx.doi.org/10.11646/zootaxa.3298.1.1 